\title{
Exploring the Key Factors Influencing the Academic Performance of First Year Students at Undergraduate Level in Bangladesh
}

\author{
Md. Solaiman Jony (Corresponding author) \\ Institute of Education and Research, Education School \\ Khulna University, Khulna, Bangladesh \\ Tel: 880-1713-400-412Ｅ-mail: jonysolaiman@gmail.com
}

\author{
Received: October 7, $2021 \quad$ Accepted: November 13, 2021
}

Published: December 1, 2021

doi:10.5296/jei.v7i2.19068 URL: https://doi.org/10.5296/jei.v7i2.19068

\begin{abstract}
Since the number of students entering into the higher education system is increasing along with the dropout rates, therefore it is important for the institutions to identify the reasons that impact students' academic performance in order to introduce the provision for necessary support for the students. This study is stimulated by the demand to determine such factors at undergraduate level that cause academic failure and dropout rates. Therefore, this study attempts to investigate what students perceive as the key influential factor that effects the academic performance of first year undergraduate students at university level. A quantitative research approach was followed to conduct the study. A survey was designed with questionnaire and was administered. Total 450 first year students, both from public and private universities in Bangladesh, were selected by convenience and stratified simple random sampling. The findings of this study disclosed that appropriate choice of course of study; students' interest in the subject; regular attendance at lectures; timely and regular examination preparation; teachers' pedagogical knowledge and skills; effective written communications skills; effective study methods are the topmost success factors that influence students' academic performance. Oppositely, lack of interest in the course content; inadequate or poor exam preparation; irregular attendance at lectures/tutorials; late submission of assignments; lack of self-discipline, self-motivation and confidence; inability to distinguish between important and unimportant information; heavy course workload; inefficient time management reverse the academic performance of the students.
\end{abstract}

Keywords: Influential factors, Academic performance, First-year university students, Higher 
education in Bangladesh, Students' performance in first year, Success factors of academic performance, Failure factors of academic performance

\section{Introduction}

In recent years, students' performance has received significant attention in the education literature. Students' academic performance is the measurement of student achievement across various academic subjects. Teachers and education officials typically measure achievement using classroom performance, graduation rates and results from standardized tests. Students' academic performance often defined students' grade point, test scores and persistence level (Finn \& Rock, 1997). There are various methods of measuring students' academic performance in terms of success and or failure and this includes: Continuous Assessment (CA), Examination, Grade Point Average (GPA), Graduation rate etc. According to Rajandran et al. (2015), Student performance is generally viewed as product of socio-economic, psychological and environmental factors. Hence, the factors are expected to vary from one country to another.

Transition from school life to university life is one of the biggest challenges the first-year university students as it presents new opportunities to the students. This transitional phase sometimes effects their academic and personal life. According to Fisher and Hood (1987), from a psychological perspective, the transition to university life often involves the need to break from the old routines and previous life-cycles as to adjust to a new living environment, including adapting to new social and residential changes and challenges which may results in an increase in psychological disturbance, depression, obsession and absent-mindedness. The challenge for first-year students also come from unrealistic beliefs about class sizes, staff availability, and workload (Lowe \& Cook, 2003; Smith \& Hopkins, 2005; Crisp et al., 2009; Kandinko \& Mawer, 2013; Hassel \& Ridout, 2018) [cited in Hien et al. (2020)]. First-year students may lack the fundamental understanding of their course (Hien et al., 2020). In result, which may impact on the academic performance of the students in their first-year study.

Study skills has been found to be a stronger and more consistent predictor of academic performance by Schmelzer et al. (1987), Killen (1994), and Hassanbeigi et al. (2011) [cited in Hien et al. (2020)]. Some of the most important ones for university success, as identified by Hassanbeigi et al. (2011), comprise time management, concentration and memory; note-taking skills; anxiety management; organisational skills; motivation and attitude, and reading comprehension skills [cited in Hien et al. (2020)].

There is an implicit assumption that, students who are admitted into a higher education institution will be capable of successfully completing the course they have registered. Therefore, the students are left out with no other options except academic success. This huge pressure on the students to become successful may impact their academic performance at the very beginning of their academic journey at university level even though they have good academic records at high school level and university entrance examination. Killen (1994) suggested that, no matter how carefully they are constructed, school matriculation examinations or special university entrance examinations are not likely to be strong predictors of success at university because they do not measure non-intellective factors that 
are related to many of the important influences on success that students encounter after they enroll at university. Killen (1994) concluded that some of the most significant factors in students' academic success at university were interest in the course, motivation, self-discipline and effort (none of which can be predicted directly from matriculation results).

There are ample of evidences in the literature on teaching and learning to suggest that factors such as teaching strategies (Bartz \& Miller, 1991), the students' motivation (Talbot, 1990), the students' approach to studying (Meyer, 1990), the interaction between students and the academic and the social systems of the university (Tinto, 1975), cultural expectations (Ginsburg, 1992), psychosocial factors (McKenzie \& Schweitzer, 2001) and numerous other factors (Watkins, 1984; Logan, 1990; Jacobi, 1991; Keef, 1992; Minnaert \& Janssen, 1992) are likely to influence students' success at university [cited in Fraser and Killen (2003)].

According to Schmelzer et al. (1987), persistent and active study was the most common reason that college students gave for their academic success. Setting appropriate goals, a good study environment, and effective time management were also considered important. Academic failure was attributed primarily to lack of study, poor time management, and inadequate goal setting.

According to Olatunji et al. (2016), studies in the past have identified study habit, student's self-concept, teacher's qualification, teaching method, school environment and government as factors influencing students' academic performance and the primary environment of the students is the home and it stands to exert tremendous impact on students' achievements.

Considering the earlier research findings on influencing factors for students' academic performance, the study to explore the key factors that influence the academic performance of first-year students at undergraduate level in Bangladesh may provide a portrait to the university students, teachers, educators and administrators to understand and take necessary intervention to address this issue regards to academic performance as very few study have been conducted on this particular issue in Bangladesh. The results of this study may work as a literature on student academic performance, and will provide necessary guideline to those who are associated with higher education management system for intervening and decision making in concern to student academic performance.

\subsection{Objective of the Study}

The objective of this study was to explore the key factors what students perceive as the highly influential for academic success and or failure at the very early stage of their academic career.

\section{Research Methodology}

The methodology of the study is described through nature of the study, the sample and sampling design, instruments of data collection, and data analysis. These are spelled out in the following sections:

This study was quantitative in nature. In quantitative research, the investigator identifies a research problem based on trends in the field or on the need to explain why something occurs (Creswell, 2012). 
A questionnaire with a list of success and failure factors was administered to collect information for the study. According to Lloyd et al. (2012) [cited in Sibanda et al. (2015)], questionnaires are considered as a reliable tool for quantitative studies. The items of the questionnaire were adopted from Killen's (1994) study on the success/failure factors that influence academic performance of students. This questionnaire was used by previous studies such as Fraser and Killen (2003, 2005), Zhang and Aasheim (2011), Ndlovu (2011), and Sibanda et al. (2015). Aside from demographic information, the questionnaire consisted of fifty (50) statements describing academic success factors and fifty-three (53) statements describing academic failure factors. These factors were ranked on a four-point Likert type questionnaire requiring participants to rank each factor from a range of 'not influential' to 'very influential' (NI = not influential, SI = slightly influential, FI = fairly influential, HI = highly influential).

One public university and one private university was chosen for the study following the convenience sampling technique. Only first year students, who have completed at least a semester were considered as a respondent based on their academic standing to accomplish the purpose for this study. Students who had a CGPA above 3.0 were considered as good academic performer or successful students, and students who had a CGPA below 2.0 were considered as poor performer or failed students. 450 students were selected by following stratified simple random sampling. Students were chosen from different academic disciplines.

In quantitative data analysis, data are analysed using mathematical procedures, called statistics. These analyses consist of breaking down the data into parts to answer the research questions (Creswell, 2012). In this study, data gathered from the questionnaire were analysed using simple descriptive methods along with appropriate regression analyses.

\section{Results of the Study}

The results from the "success factor" statements of the questionnaire are presented first, then the results from the "failure factor" statements are discussed followed by overall discussion.

\subsection{Success Factor Statement Responses}

Items on success factor for academic performance covered the range from 1 (Not Influential) to 4 (Highly Influential). The mean score with standard deviation of the responses given by first-year students ranged from 3.79 for 'Appropriate choice of course of study' to 2.61 for 'Encouragement, motivation and support from peer'. Subsequently, Students' interest in the subject (mean 3.72); Regular attendance at lectures (mean 3.71); Timely and regular examination preparation (mean 3.68); Teachers' pedagogical knowledge and skills (mean 3.63); Effective written communications skills (mean 3.59); Effective study methods (mean 3.57); Medium of study (English/Bangla) (mean 3.56); Teachers' professional knowledge and credentials (mean 3.52); Self-confidence (mean 3.49); Teachers who can inspire students' (mean 3.48); Tutorial support (mean 3.46); Self-motivation (mean 3.45); Self-discipline (mean 3.43); Regular study practice and Teacher student relationship (mean 3.41) are the topmost success factors that influence students' academic performance (Table 1). 
Table 1. Comparison of mean ratings on 'success factor' items from first-year students

\begin{tabular}{|c|c|c|}
\hline Question Items & Mean & Std. Deviation \\
\hline Appropriate choice of course of study & 3.79 & 0.498 \\
\hline Students' interest in the subject & 3.72 & 0.491 \\
\hline Regular attendance at lectures & 3.71 & 0.821 \\
\hline Timely and regular examination preparation & 3.68 & 0.498 \\
\hline Teachers' pedagogical knowledge and skills & 3.63 & 0.749 \\
\hline Effective written communications skills & 3.59 & 0.491 \\
\hline Effective study methods & 3.57 & 0.633 \\
\hline Medium of study (English/Bangla) & 3.56 & 0.401 \\
\hline Teachers' professional knowledge and credentials & 3.52 & 0.498 \\
\hline Self-confidence & 3.49 & 0.495 \\
\hline Teachers who can inspire students' & 3.48 & 0.398 \\
\hline Tutorial support & 3.46 & 0.491 \\
\hline Self-motivation & 3.45 & 0.489 \\
\hline Self-discipline & 3.43 & 0.491 \\
\hline Regular study practice & 3.41 & 0.401 \\
\hline Teacher student relationship & 3.41 & 0.401 \\
\hline An appropriate balance between academic commitments and social life & 3.35 & 0.403 \\
\hline The desire to learn & 3.34 & 0.749 \\
\hline Financial security & 3.31 & 0.493 \\
\hline Consistent effort of the learners & 3.27 & 0.749 \\
\hline Creative and critical thinking ability & 3.24 & 1.021 \\
\hline Clear understanding of teachers' expectation by the students' & 3.23 & 0.491 \\
\hline Family support & 3.22 & 0.401 \\
\hline Encouragement, motivation and support from teachers' & 3.21 & 0.491 \\
\hline Satisfactory accommodation & 3.19 & 0.401 \\
\hline A stable personal life & 3.17 & 0.981 \\
\hline Linkage of the study subjects with career goal & 3.14 & 0.406 \\
\hline Regular and comprehensive feedback by teachers' & 3.13 & 0.801 \\
\hline General academic ability & 2.99 & 0.491 \\
\hline Willingness to ask for help from peers & 2.97 & 0.491 \\
\hline Regular use of the library & 2.97 & 0.401 \\
\hline Hard work, commitment and dedication & 2.96 & 0.633 \\
\hline Effective examination techniques & 2.95 & 0.401 \\
\hline
\end{tabular}




\begin{tabular}{|l|l|l|}
\hline Support from peer group & 2.93 & 0.491 \\
\hline Adaptability with University procedures and guidelines & 2.91 & 0.401 \\
\hline Ability to work as a member of a group & 2.89 & 0.491 \\
\hline Clear guideline with expected learning outcome & 2.89 & 0.749 \\
\hline Ability to learn independently & 2.89 & 0.301 \\
\hline Willingness to ask for help from teachers' & 2.88 & 0.749 \\
\hline Encouragement, motivation and support from parents' & 2.88 & 0.749 \\
\hline Availability of quality learning resources & 2.82 & 0.765 \\
\hline Ability to manage stress & 2.81 & 0.401 \\
\hline Implementation of theory into practice & 2.81 & 0.633 \\
\hline Involvement in co-curricular activities & 2.61 & 0.633 \\
\hline Access to resources such as libraries and internet & 2.77 & 1.097 \\
\hline Positive influence of friends & 2.96 & 0.301 \\
\hline Student's attitude towards learning & 2.75 & 0.633 \\
\hline Continuous assessment & 2.71 & 0.633 \\
\hline Willingness to accept academic challenge & 2.66 & 0.633 \\
\hline Encouragement, motivation and support from peer & 2.61 & 0.749 \\
\hline
\end{tabular}

\subsection{Failure Factor Statement Responses}

The items on failure factor also covered the range from 1 (Not Influential) to 4 (Highly Influential). The item most likely to contribute to student failure by first-year students was 'Lack of interest in the course content' (mean 3.68). The item rated lowest which contributed to student failure was 'Part-time job by the students' (mean 2.32). Other uppermost failure factors influencing students' academic performance included: Inadequate or poor exam preparation (mean 3.62); Irregular attendance at lectures/tutorials (mean 3.62); Late submission of assignments (mean 3.54); Lack of self-discipline (mean 3.51); Lack of self-motivation (mean 3.49); Lack of confidence (mean 3.45); Inability to distinguish between important and unimportant information (mean 3.45); Heavy course workload (mean 3.44); Inefficient time management (mean 3.42); Previous poor academic foundation (mean 3.41); Insufficient effort (e.g., study, exam prep) (mean 3.39); Personal or family crisis (mean 3.39); Financial problems (mean 3.35); Poor study techniques (mean 3.34) and so on (Table 2). 
Table 2. Comparison of mean ratings on 'failure factor' items from first-year students

\begin{tabular}{|c|c|c|}
\hline Question Items & Mean & Std. Deviation \\
\hline Lack of interest in the course content & 3.68 & 0.621 \\
\hline Inadequate or poor exam preparation & 3.62 & 0.491 \\
\hline Irregular attendance at lectures/tutorials & 3.62 & 0.749 \\
\hline Late submission of assignments & 3.54 & 0.491 \\
\hline Lack of self-discipline & 3.51 & 0.498 \\
\hline Lack of self-motivation & 3.49 & 0.495 \\
\hline Lack of confidence & 3.45 & 0.49 \\
\hline Inability to distinguish between important and unimportant information & 3.45 & 0.633 \\
\hline Heavy course workload & 3.44 & 0.633 \\
\hline Inefficient time management & 3.42 & 0.401 \\
\hline Previous poor academic foundation & 3.41 & 0.749 \\
\hline Insufficient effort (e.g., study, exam prep) & 3.39 & 0.81 \\
\hline Personal or family crisis & 3.39 & 0.638 \\
\hline Financial problems & 3.35 & 0.451 \\
\hline Poor study techniques & 3.34 & 0.398 \\
\hline Badly structured presentations by lecturers & 3.33 & 0.491 \\
\hline Poor study skills of students & 3.32 & 0.749 \\
\hline Boring presentations by lecturers & 3.31 & 0.701 \\
\hline Unclear criteria and lecturers' expectations of assignments & 3.29 & 0.401 \\
\hline Textbooks available in one language only & 3.29 & 0.635 \\
\hline Inability to balance study and social commitments & 3.27 & 0.491 \\
\hline Too much dependency on directions/guidance by teachers' & 3.23 & 0.749 \\
\hline Teachers' lacking to understand the needs of students' & 3.21 & 0.491 \\
\hline Inappropriate and biased assessment procedures by teachers & 3.21 & 0.749 \\
\hline Lack of persistence & 3.19 & 0.489 \\
\hline Low self esteem & 3.13 & 0.921 \\
\hline Inability to cope with stress & 3.13 & 0.491 \\
\hline Failure to approach lecturers/tutors for help & 3.12 & 0.491 \\
\hline Lack of self-assessment & 3.11 & 0.801 \\
\hline Lack of academic ability & 2.99 & 0.401 \\
\hline Personal clash with the teachers & 2.99 & 0.633 \\
\hline Lack of ability to bridge between theory and practice & 2.96 & 0.491 \\
\hline Too many extra unnecessary interests & 2.95 & 0.921 \\
\hline
\end{tabular}




\begin{tabular}{|c|c|c|}
\hline Poor examination techniques & 2.94 & 0.491 \\
\hline Low input from lecturers to motivate the students & 2.93 & 0.981 \\
\hline Poor language abilities of lecturers & 2.92 & 0.401 \\
\hline Laziness or apathy & 2.91 & 0.491 \\
\hline Misinterpretation of course requirements & 2.91 & 0.749 \\
\hline Fear of failure & 2.89 & 1.097 \\
\hline Too many demands on students' time & 2.88 & 0.401 \\
\hline Inability to make use of higher order thinking skills & 2.86 & 0.497 \\
\hline Failure to understand the depth of understanding required at tertial level & 2.83 & 0.401 \\
\hline Lack of a clear career goal & 2.81 & 0.401 \\
\hline Inadequate university library facilities & 2.81 & 0.459 \\
\hline Lack of communication between teacher and student & 2.78 & 0.401 \\
\hline Lack of rewards for student efforts & 2.77 & 0.821 \\
\hline Lack of maturity from the students' & 2.65 & 0.633 \\
\hline Influence of Peer group & 2.64 & 0.901 \\
\hline Teachers' unrealistic high expectations on students & 2.62 & 0.401 \\
\hline Health and well being & 2.61 & 0.301 \\
\hline Noisy classroom environment & 2.56 & 0.749 \\
\hline
\end{tabular}

\section{Discussion}

Findings from this study support the previous research findings and existed literature that appropriate choice of course of study; students' interest in the subject; regular attendance at lectures; timely and regular examination preparation; teachers' pedagogical knowledge and skills; effective written communications skills; effective study methods; teachers' professional knowledge and credentials; self-confidence; self-motivation and self-discipline of student are the topmost key success factors academic performance. On the other hand, lack of interest in the course content; inadequate or poor exam preparation; irregular attendance at lectures/tutorials; late submission of assignments; lack of self-discipline, self-motivation and confidence; inability to distinguish between important and unimportant information; heavy course workload; inefficient time management; previous poor academic foundation; insufficient study effort; personal or family crisis; financial problems; poor study techniques; badly structured and boring presentations by lecturers are few of the many factors which cause failure for the students (Figure 1). 


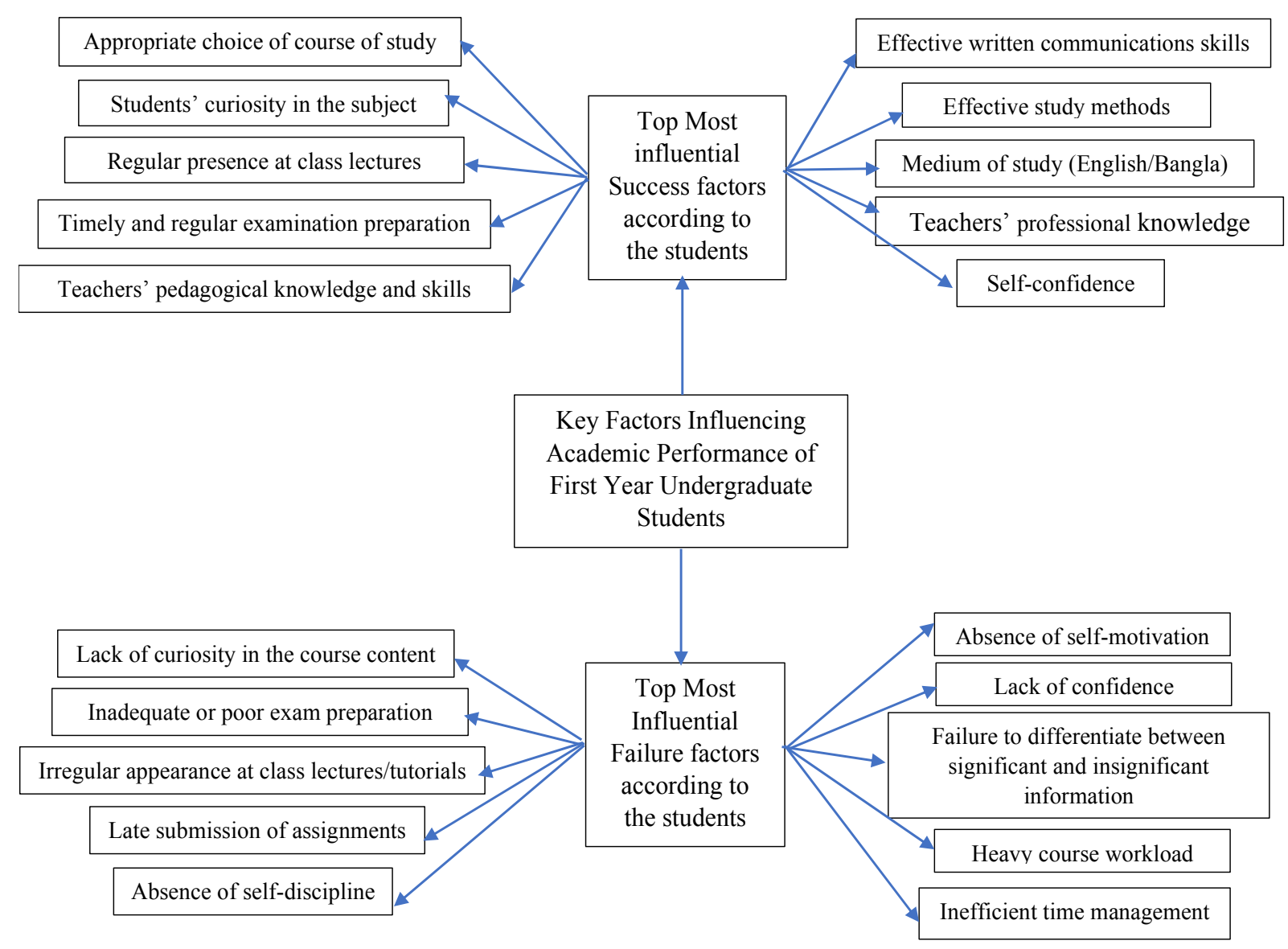

Figure 1. Key factors influencing academic performance of first year undergraduate students

In Bangladesh, students and their family give huge emphasis on course selection at university level based on the future job market. Parents and students feel secured if students can enroll into a course which can help them to ensure future job security. Thus, the opportunity of appropriate choice of course at university gives massive advantage to the students. At the same time, students who are not in their choice of course feel enormous pressure and their performance is also hampered.

Another significant factor impacting students' academic performance was regular class attendance and timely examination preparation and assignment submission. Students perceived these factors as crucial for their academic success or failure. As per the finding of this study, for first-year students, self-confidence; self-motivation and self-disciplines are the most important personal traits which determines the success and failure at university level. Writing skill works as a controlling factor for students' to be successful in their university life as written assessment is the main method to evaluate students' academic performance in Bangladesh, Therefore, effective written communications skills was ranked as top-level influencing success factor by the first-year students.

The findings suggests that, teachers' content knowledge, pedagogical knowledge, skills and relation with students also works as controlling factors for student's performance. This 
finding supports M. Bamidele and A. Bamidele (2013) assertion that teachers/lectures are key factor for student's success. Kunter et al. (2008) [cited in Hien et al. (2020)], found that enthusiastic teaching, characterized with teachers' express style and energetic, animated, inspiring teaching, particularly produces high-quality learning and is indicative of student outcomes and interest.

In the context of this study, learning conditions like family support; encouragement, motivation and support from teachers', good accommodation; stable personal life; support from peers; availability of quality learning resources; regular use of the library; adaptability with university procedures and guidelines create a positive impact on students' academic life. Oppositely, inability to cope with stress; failure to approach lecturers/tutors for help; lack of self-assessment; too many extra unnecessary interests; procrastination; fear of failure; inadequate university library; lack of maturity from the students'; influence of peer group impact academic performance in reverse.

\section{Conclusion}

The results of the study provide an important insight into the factors that affects first-year student's academic performance. The results of this study cannot be generalized to other contexts although the results support findings from several earlier studies. Further research might consider increasing the population size to gain much deeper insights into the perceptions. It may also help to undertake a different research methodology to understand the influencing factors for students' academic performance.

\section{References}

Anderton, R. S. (2017). Identifying factors that contribute to academic success in first year allied health and science degrees at an Australian university. Australian Journal of Education, 61(2), 184-199. https://doi.org/10.1177/0004944117713321

Ayodele, T. O., Oladokun, T. T., \& Gbadegesin, J. T. (2016). Factors influencing academic performance of real estate students in Nigeria. Property Management, 34(5), 396-414. https://doi.org/10.1108/PM-09-2015-0045

Bamidele, M., \& Bamidele, A. (2013). Influence of Cognitive Performance on Mathematics Student's Level of Achievement. International Researcher, 2(1), 142-150.

Briggs, A. R. J., Clark, J., \& Hall, I. (2012). Building bridges: Understanding student transition to university. Quality in Higher Education, 18(1), 3-21. https://doi.org/10.1080/ 13538322.2011 .614468

Cresswell, J. W. (2012). Educational Research: Planning, Conducting, and Evaluating Quantitative and Qualitative Research (4th ed.). Pearson Education Inc.

Crisp, G., Palmer, E., Turnbull, D., Nettelbeck, T., Ward, L., LeCouteur, A., ... Schneider, L. (2009). First year student expectations: Results from a university-wide student survey. Journal of University Teaching and Learning Practice, 6(1), 11-26. https://doi.org/10.53761/ 1.6.1.3 
Finn, J. D., \& Rock, D. A. (1997). Academic success among students at risk for school failure. The Journal of Applied Psychology, 82(2), 221-234. https://doi.org/10.1037/0021-9010. 82.2.221

Fisher, S., \& Hood, B. (1987). The stress of the transition to university: A longitudinal study of psychological disturbance, absent-mindedness and vulnerability to homesickness. British Journal of Psychology, 78(4), 425-441. https://doi.org/10.1111/j.2044-8295.1987.tb02260.x

Fraser, W. J., \& Killen, R. (2003). Factors influencing academic success or failure of first-year and senior university students: Do education students and lecturers perceive things differently? South African Journal of Education, 23(4), 254-263.

Hassanbeigi, A., Askari, J., Nakhjavani, M., Shirkhoda, S., Barzegar, K., Mozayyan, M. R., \& Fallahzadeh, H. (2011). The relationship between study skills and academic performance of university students. Procedia-Social and Behavioral Sciences, 30, 1416-1424. https://doi.org/10.1016/j.sbspro.2011.10.276

Hassel, S., \& Ridout, N. (2018). An investigation of first-year students' and lecturers' expectations of university education. Frontiers in Psychology, 8(2218), 1-13. https://doi.org/10.3389/fpsyg.2017.02218

Hien, T. T. L., Hang, T. T. N., Thuy, P. L., Trinh, T. T. L., Nhi, T. N., Tram, P. T. N., \& Trung, T. (2020). Factors Affecting Academic Performance of First-Year University Students: A Case of a Vietnamese University. International Journal of Education and Practice, 8(2), 221-232. https://doi.org/10.18488/journal.61.2020.82.221.232

Killen, R., (1994). Differences between students' and lecturers' perceptions of factors influencing students' academic success at university. Higher Education Research and Development, 13(2), 199-211. https://doi.org/10.1080/0729436940130210

Lowe, H., \& Cook, A. (2003). Mind the gap: Are students prepared for higher education? Journal of Further and Higher Education, 27(1), 53-76. https://doi.org/10.1080/0309877 0305629

Mahmud, A., Antor, S. C., \& Al Zabir, A. (2020). Factor Affecting the Academic Performance of University Students: Evidence from Sylhet. Social Work and Education, 7(3), 373-382. https://doi.org/10.25128/2520-6230.20.3.11.

Mortuza Ahmmed, M., \& Salim, Z. R. (2018). Determinants of Academic Performance of Undergraduate Students in Private Universities in Bangladesh: A Case Study. Global Journal of Human-Social Science (G): Linguistics \& Education, 16(11), 28-34.

Ndlovu, M. C. (2011). Students' perceptions of the in-service training for the Advanced Certificate in Education programme. South African Journal of Higher Education, 25(3), 523-541.

Olatunji, S. O., Aghimien, D. O., Oke, A. E., \& Olushola, E. (2016). Factors Affecting Performance of Undergraduate Students in Construction Related Disciplines. Journal of Education and Practice, 7(13), 55-62. 


\section{Macrothink

Rajandran, K., Hee, T., Kanawarthy, S., Soon, L., Kamaludin, H., \& Khezrimotlagh, D. (2015). Factors Affecting First Year Undergraduate Students Academic Performance. Scholars Journal of Economics, Business and Management, 2(1A), 54-60.

Schmelzer, R. V., Schmelzer, C. D., Figler, R. A., \& Brozo, W. G. (1987). Using the critical incident technique to determine reasons for success and failure of university students. Journal of College Student Personnel, 28, 261-266.

Sibanda, L., Iwu, C. G., \& Benedict, O. H. (2015). Factors influencing academic performance of university students. Demography and Social Economy, 2(24), 103-115. https://doi.org/ $10.15407 /$ dse2015.02.103

Smith, K., \& C. Hopkins. (2005). Great expectations: Sixth-formers' perceptions of teaching and learning in degree-level English. Arts and Humanities in Higher Education, 4(3), 304-318. https://doi.org/10.1177/1474022205056173

York, T. T., Gibson, C., \& Rankin, S. (2015). Defining and Measuring Academic Success. Practical Assessment, Research, and Evaluation, 20(1), 1-20. https://doi.org/10.7275/ hz5x-tx03

Zhang, A., \& Aasheim, C. L. (2011). Academic success factors: An IT student perspective. Journal of Information Technology Education, 10, 309-331. https://doi.org/10.28945/1518

\section{Copyright Disclaimer}

Copyright for this article is retained by the author(s), with first publication rights granted to the journal.

This is an open-access article distributed under the terms and conditions of the Creative Commons Attribution license (http://creativecommons.org/licenses/by/3.0/). 